УДК 903.23 (477.7)

DOI: https://doi.org/10.33782/eminak2019.1(25).215

\title{
АМФОРЫ ТИПА 27 ПО КЛАССИФИКАЦИИ В.В. КРАПИВИНОЙ ИЗ ТИРЫ
}

\author{
Денис Масюта \\ Одесский археологический музей НАН Украины (Одесса, Украина) \\ e-mail: masuta.denis@gmail.com \\ ORCID: https://orcid.org/0000-0002-3722-154X
}

До наукового обігу вводяться знахідки амфор типу 27 по класифікації В.В. Крапівіної, виявлені при дослідженні Тіри. Приділяється увага питанням їх морфології та хронології, вказуються візуальні особливості керамічного тіста, характерні для досліджуваного різновиду амфорної тари. Визначається ареал поширення таких посудин. Запропоновано припущення про те, що розглянуті амфори призначалися для транспортування солоної риби та надходили до Тіри з території Боспору протягом III cm. н.е.

Ключові слова: амфорна тара, морфологія, хронологія, пізньоримський час, Тіра

В римское время, как и в предшествующую эллинистическую эпоху, Тира играла роль важного центра посреднической торговли между античными городами и варварским населением Нижнего Поднестровья. Тесные торгово-экономические взаимоотношения с производственными центрами Средиземноморья и Причерноморья нашли отражение в археологических находках из Тиры, среди которых наиболее многочисленную категорию составляет амфорная тара. За последние два десятилетия, в результате планомерных археологических исследований этого памятника, был накоплен выразительный материал, позволяющий дополнить состав керамического комплекса Тиры римского времени несколькими разновидностями амфорной тары ${ }^{1}$. К одним из наиболее редких следует отнести амфоры типа 27 по классификации В.В. Крапивиной.

Впервые такие сосуды были введены в научный оборот в 1959г. в предварительной публикации результатов исследований варварского могильника «Совхоз № 10» в округе Херсонеса, где они использовались в качестве погребальных урн 2 . Отдельные находки подобных амфор на античных памятниках Северного Причерноморья известны с 80-х гг. ХХ в. ${ }^{3}$ В 1993 г. В.В. Крапивина, при построении классификации керамической тары Ольвии, объединила эти амфоры в один тип ${ }^{4}$. Позднее аналогичные сосуды были отнесены к типу Х по классификации, разработанной для

\footnotetext{
${ }^{1}$ Археологические исследования осуществлялись Белгород-Тирской экспедицией Института археологии НАН Украины под руководством Т.Л.Самойловой, которой автор выражает благодарность за предоставленную возможность публикации находок.

2 Стржелецкий С.Ф. Позднеантичный могильник в Инкерманской долине // Краткие сообщения Института археологии АН УССР. 1959. № 8. С. 141, 145, Рис. 4.

3 Лейпунская Н.А. Керамика из затопленной части Ольвии // Античная культура Северного Причерноморья (отв. ред. С.Д. Крыжицкий). Киев: Наукова думка, 1984. С. 75, 76, Рис. 3, 1; Античные государства Северного Причерноморья // Археология СССР. Москва: Наука, 1984. Табл. LXXIV, 18; Гайдукевич В.Ф. Античные города Боспора. Мирмекий. Ленинград: Наука, 1987. С. 171, Рис. 191.

${ }^{4}$ Крапивина В.В. Ольвия. Материальная культура I-IV вв. н.э. Киев: Наукова думка, 1993. С. 98 , Рис. 30, 25.
} 
амфорной тары могильника «Совхоз № $10 » 5$.

Цель нашей работы заключается в публикации обнаруженных в Тире находок амфор типа 27 по В.В. Крапивиной и тщательном изучении этой разновидности керамической тары. Для ее достижения необходимо решение следующих задач: исследование археологических комплексов Тиры, содержащих эти амфоры, поиск аналогий, уточнение морфологии, хронологии, определение содержимого сосудов, а также локализация предполагаемого места их производства.

К типу 27 по В.В. Крапивиной относятся сосуды с очень широким, высоким, почти цилиндрическим рифленым горлом, туловом яйцевидной формы и ножкой в виде высокого кольцевого поддона. Ручки таких амфор широкие, овальные в сечении, их внешняя поверхность профилирована двумя или тремя продольными желобками, реже - одной широкой выемкой-врезом. Одним концом они крепятся к горлу, чуть ниже венца, другим - к нижней части плечиков сосуда. Для большинства экземпляров характерны припухлость в верхней части горла и скошенный внутрь клювовидный венец, с выемкой на внешней поверхности (рис. 1, 1)6. Высота амфор варьируется в пределах 49-54 см. Диаметр венца равен 16-18 см при максимальном диаметре тулова 24-28 см, диаметр дна колеблется от 8 до 10 см7. Их объем составляет 10 литров ${ }^{8}$.

Из затопленной части Ольвии происходят две амфоры, которые, безусловно, соответствуют рассматриваемому типу, но отличаются меньшими размерами и валикообразной формой венцов (рис. 2, 6, 7)9. Общая высота этих сосудов равна 30-31 см, диаметр горла - 10 см, максимальный диаметр тулова составляет 16-18 см ${ }^{10}$.

Основываясь на морфологических отличиях, амфоры типа 27 по В.В. Крапивиной можно, предварительно, разделить на два варианта (а и b). К варианту 27а следует отнести более крупные сосуды с клювовидными венцами, а к 27b - небольшие изделия, венец которых оформлен в виде валика.

Все амфоры рассматриваемого типа изготовлены из плотной, хорошо обожженной глины, содержащей большое количество известняковых частиц, а также примесей железистых включений. Необходимо отметить, что если визуально различимый состав керамического теста интересующих нас амфор одинаков ${ }^{11}$, то его цвет у разных сосудов может отличаться и быть темно-красного, бежевого, розовато-

\footnotetext{
${ }^{5}$ Стржелецкий С.Ф., Высотская Т.Н., Рыжова Л.А., Жесткова Г.И. Население округи Херсонеса в первой половине I тысячелетия новой эры (по материалам некрополя «Совхоз № 10») // Stratum plus. 2005. № 4. C. 71, Табл. VI, 6.

${ }_{6}^{6}$ Арсеньева Т.М., Науменко С.А. Усадьбы Танаиса. Москва: ИА РАН, 1992. Рис. 38, 1; Krapivina V. Amphorae of the $3^{\text {rd }} 4^{\text {th }}$ centuries A.D. in Olbia Pontica // Production and Trade of Amphorae in the Black Sea. PATABS I: Actes de la Table Ronde internationale de Batoumi et Trabzon, 27-29 Avril 2006 // Varia Anatolica. XXI. Istanbul-Paris. 2010. Pl. 39, 2; Opaiţ A. A weighty matter: pontic fish amphorae // The Black Sea in antiquity: Regional and interregional economic exchanges. Black Sea Studies 6. Aarhus: Aarhus University Press, 2007. Fig. 24

${ }^{7}$ Арсеньева Т.М., Науменко С.А. Указ. соч. С. 157, Рис. 38, 1.

8 Науменко С.А. Состав амфор в закрытых комплексах Танаиса конца I - середины III вв. н.э. // Вестник Танаиса. 2012. Вып. 3. С. 72.

9 Лейпунская Н.А. Указ. соч. С. 75, 76, Рис. 3, 1; Крапивина В.В. Указ. соч. С. 98, Рис. 30, 25; Ольвия. Античное государство в Северном Причерноморье / С.Д. Крыжицкий и др. Киев: Изд-во ИА НАНУ, 1999. Рис. 106.

10 Крапивина В.В. Указ. соч. С. 98.

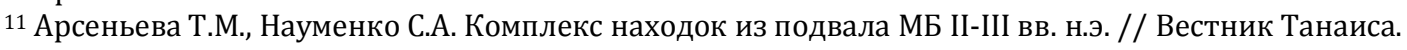
1994. Вып. 1. С. 70.
} 
лилового ${ }^{12}$ или красно-оранжевого 13 оттенков. Такую вариабельность цветовой гаммы можно объяснить изменениями режима обжига керамики. Внешняя поверхность амфор зачастую покрыта ангобом белого или бежевого цвета.

В ходе археологических раскопок Тиры выявлены сосуды обоих морфологических вариантов исследуемого типа. Амфоры варианта 27а представлены фрагментами профильных частей, большинство из которых было обнаружено в 2015 г. Так, из слоя, датирующегося I-III вв. н.э., происходит обломок округлого клювовидного венца, диаметр которого составляет 16 см (рис. 1, 4). Его поверхность была покрыта светлым ангобом, а глина имела красно-оранжевый цвет ${ }^{14}$.

В слое засыпи сооружения № 1080 найдена овальная в сечении ручка красноглиняной амфоры, внешняя поверхность которой профилирована одной выемкойврезом (рис. 1,5). Из этого комплекса происходит обломок клювовидного венца с острым краем, который также относится к сосуду варианта 27a, однако принадлежит другому экземпляру (рис. 1, 2). Он изготовлен из красно-оранжевой глины, а его поверхность покрыта светлым ангобом. Диаметр венца равен 18 см. Вместе с рассматриваемыми фрагментами обнаружены обломки керамических сосудов как римского времени (I-IV вв. н.э.), так и золотоордынского периода (XIII-XIV вв.) ${ }^{15}$.

Близкий по форме, а также аналогичный по цвету теста и ангоба обломок венца был найден в 2016 г. при зачистке оплыва вдоль борта раскопа. Под венцом, диаметр которого составляет 17 см, сохранилась рифленая стенка (рис. 1, 3).

К варианту $27 \mathrm{~b}$ можно отнести фрагментированный ангобированный сосуд на высоком кольцевом поддоне, обнаруженный в 2000 г. при исследовании переотложенного напластования, залегавшего между строительными остатками средневекового времени ${ }^{16}$. Верхняя часть его рифленого горла, а также ручки утрачены. Максимальный диаметр амфоры, которая была восстановлена на высоту 24,5 см, составляет 18,7 см, а диаметр дна - 7,5 см (рис. 1, 7).

Аналогичная амфора хранится в фондах Белгород-Днестровского краеведческого музея (шифр ИОИКМ, А-4283, КП 37868). Ее ручки и венец также утрачены. Сосуд сохранился на высоту 31,5 см, максимальный диаметр тулова равен 18 см, диаметр поддона составляет 7 см. Поддон асимметричный, что влияет на устойчивость амфоры (рис. 1, 6). Керамическая масса красного цвета, по составу тождественна другим сосудам исследуемого типа, поверхность покрыта характерным белым ангобом, который сохранился лишь частично. Предмет поступил на хранение в 1948 г., однако точное место и обстоятельства его обнаружения неизвестны. В этот год исследования Тиры не осуществлялись. Возможно, рассматриваемая находка была сделана в 1947 г., в ходе работ на памятнике Белгород-Днестровской археологической экспедиции ИА НАН УССР под руководством Л.Д. Дмитрова.

\footnotetext{
12 Арсеньева Т.М., Науменко С.А. Усадьбы... С. 157.

13 Krapivina V. Op. cit. P. 70.

14 Самойлова Т.Л., Остапенко П.В., Богуславский Г.С., Смольянинова С.П., Старкин А.В., Ветчинникова Н.Е. Отчет о работе Белгород-Тирской экспедиции на городище «античная Тира средневековый Белгород» в 2015 г. Белгород-Днестровский-Одесса, 2015. С. 6, 7, 153.

15 Ibid. C. 6-8, 12, 13, 132, 147.

16 Самойлова Т.Л., Кожокару В., Смольянинова С.П., Батизат Г.В., Богуславский Г.С. Отчет о работе украино-румынской Белгород-Тирской экспедиции в 2000 г. Белгород-Днестровский-Одесса, 2001. С. 7, Табл. 9, 2; Самойлова Т.Л., Кожокару В., Богуславский Г.С. Античная Тира средневековый Белгород (отчет о раскопках за 1996-1999 гг.). Tyras - Cetatea Albă / BelhorodDnistros'kyj. Săpături 1996-1999 (edited by P. Roman, S. Kryzickij). Buharesti, 2002. № I. Табл. LXVIII, 1.
} 

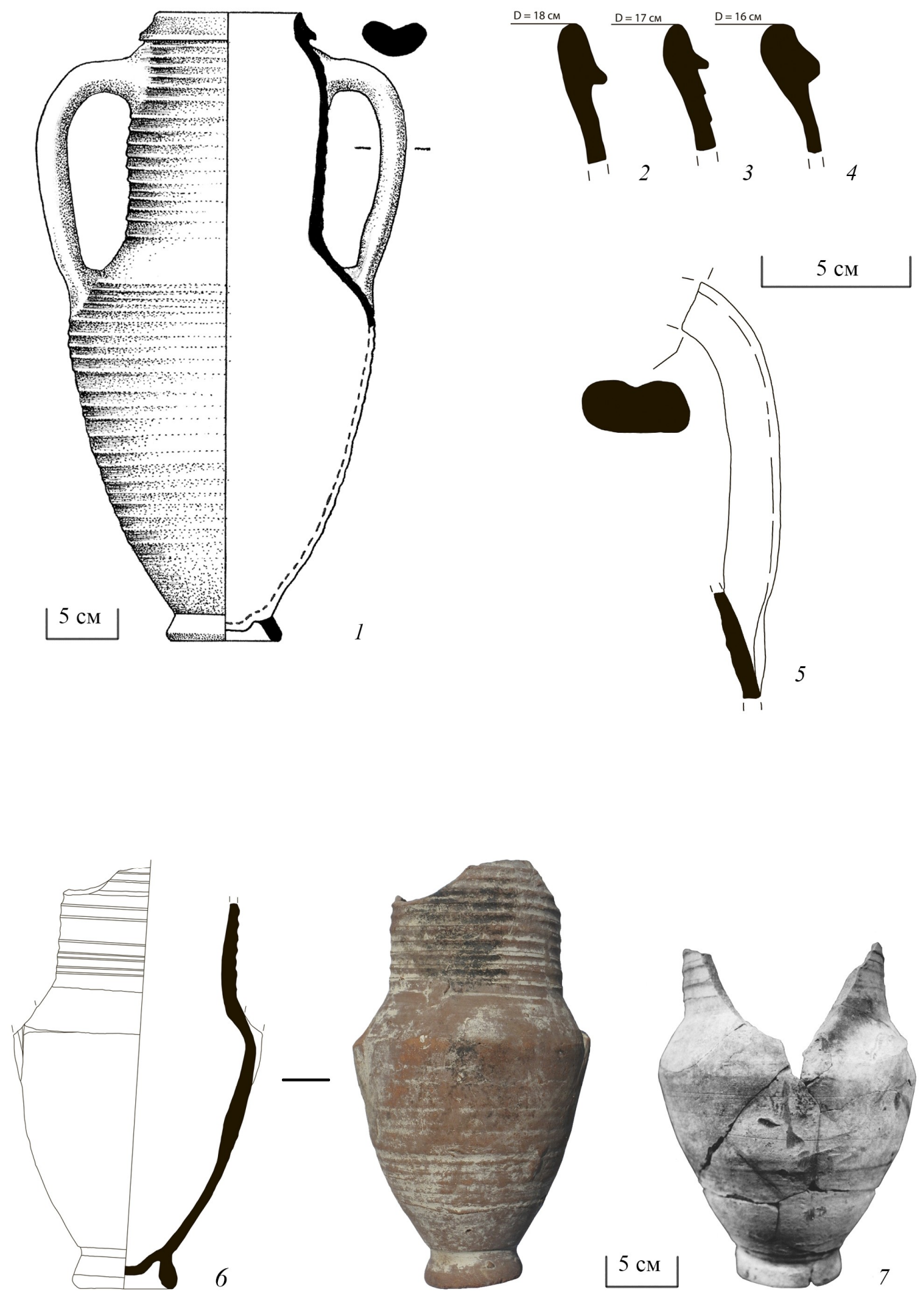

Рис. 1. Амфоры типа 27 по В.В. Крапивиной. Варианты а (1-5) и b $(6,7)$. 1 - «Совхоз № 10» (по: Opaiţ А., 2007); 2-7 - Тира. 
Интересующая нас разновидность тары довольно редкая и за пределами понтийского региона не встречается (рис. 3). Она преимущественно представлена сосудами варианта 27a, находки которых зафиксированы при исследовании античных городов Северного Причерноморья: Горгиппии (рис. 2, 3) ${ }^{17}$, Танаиса (рис. 2, 1,2)18, Мирмекия ${ }^{19}$, Ольвии (рис. 2, 5) 20, Херсонеса 21 . При раскопках поселения на высоте Безымянной, расположенной на небольшом удалении от последнего, выявлена половина амфоры исследуемого типа22. Кроме того, четыре целых экземпляра происходит из могильника «Совхоз № 10», который также находился в округе Херсонеса (рис. 2,4$)^{23}$. В Западном Причерноморье они очень редки - единственный фрагмент амфоры, который может принадлежать к интересующей нас разновидности, был обнаружен в Каллатисе 24 . В южной и восточной частях причерноморского региона эти сосуды распространения не получили. Судя по опубликованным материалам, находки амфор варианта 27b известны лишь в Тире и Ольвии.

Как было указано выше, находки амфор варианта 27а происходят из археологических контекстов Тиры с довольно широкой датировкой. В Горгиппии такой сосуд был отнесен к II-III вв. н.э. ${ }^{25}$, аналогичная амфора из Мирмекия датируется II - серединой III вв. н.э. ${ }^{26}$ Для уточнения времени их бытования важное значение имеют материалы археологических исследований Танаиса, куда они поступали в течение первой половины III ст. н.э. ${ }^{27}$ Интересно, что сразу три таких амфоры находились в подвале усадьбы, разрушенной в пожаре во время разгрома города в середине III в. н.э. ${ }^{28}$ Рассматриваемая разновидность амфорной тары продолжала бытовать и во второй половине столетия. Так, к этому времени относят сосуд с высоты Безы-

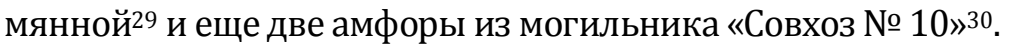

Обнаруженные в Тире амфоры варианта $27 \mathrm{~b}$, по аналогии с уже упоминавшимися экземплярами из затопленной части Ольвии, также могут быть отнесены к III в. н.э., однако эта датировка носит предположительный характер 31.

Таким образом, амфоры типа 27 по В.В. Крапивиной производились на протяжении всего III в. н.э. Пока не ясно, как хронологически соотносятся друг с другом его морфологические варианты. Возможно, ответ на этот вопрос будет получен в дальнейшем, после получения репрезентативной выборки надежно датируемых экземпляров.

\footnotetext{
17 Античные государства... Табл. LXXIV, 18; Алексеева Е.М. Античный город Горгиппия. Москва: Эдиториал УРСС, 1997. Табл. 119, 3, 224, 4.

18 Арсеньева Т.М., Науменко С.А., Усадьбы... С. 157, Рис. 38, 1; Их же. Комплекс находок... С. 69-70, Рис. 12, 2; Науменко С.А. Указ. соч. С. 71, 72, Рис. 13, 5; 15, 7.

19 Гайдукевич В.Ф. Указ. соч. С. 171, Рис. 191.

${ }^{20}$ Krapivina V. Op. cit. P. 70, 71, Pl. 39, 2.

21 Opait A., Ionescu M. Contributions to the economic life of the city of Callatis in light of new ceramic finds $\left(2^{\text {nd }} 6^{\text {th }}\right.$ centuries AD) // Arheologia Moldovei. 2016. XXXIX. P. 70.

22 Opaiţ A. Op. cit. P. 116.

${ }^{23}$ Стржелецкий С.Ф., Высотская Т.Н., Рыжова Л.А., Жесткова Г.И. Указ. соч. С. 71, Табл. VI, 6; Opaiţ A. Op. cit. P. 115, 116, Fig. 24.

24 Opaiţ A., Ionescu M. Op. cit. P. 70, Pl. XVI, 100.

25 Алексеева Е.М. Указ. соч. Табл. 224, 4.

26 Гайдукевич В.Ф. Указ. соч. С. 171.

27 Арсеньева Т.М., Науменко С.А. Усадьбы... С. 157.

28 Арсеньева Т.М., Науменко С.А., Комплекс находок..., С. 69, 70.

${ }^{29}$ Opaiţ̧ A. Op. cit. P. 116.

30 Стржелецкий С.Ф., Высотская Т.Н., Рыжова Л.А., Жесткова Г.И. Указ. соч. С. 71.

31 Лейпунская Н.А. Указ. соч. С. 75, 76; Крапивина В.В. Указ. соч. С. 98.
} 

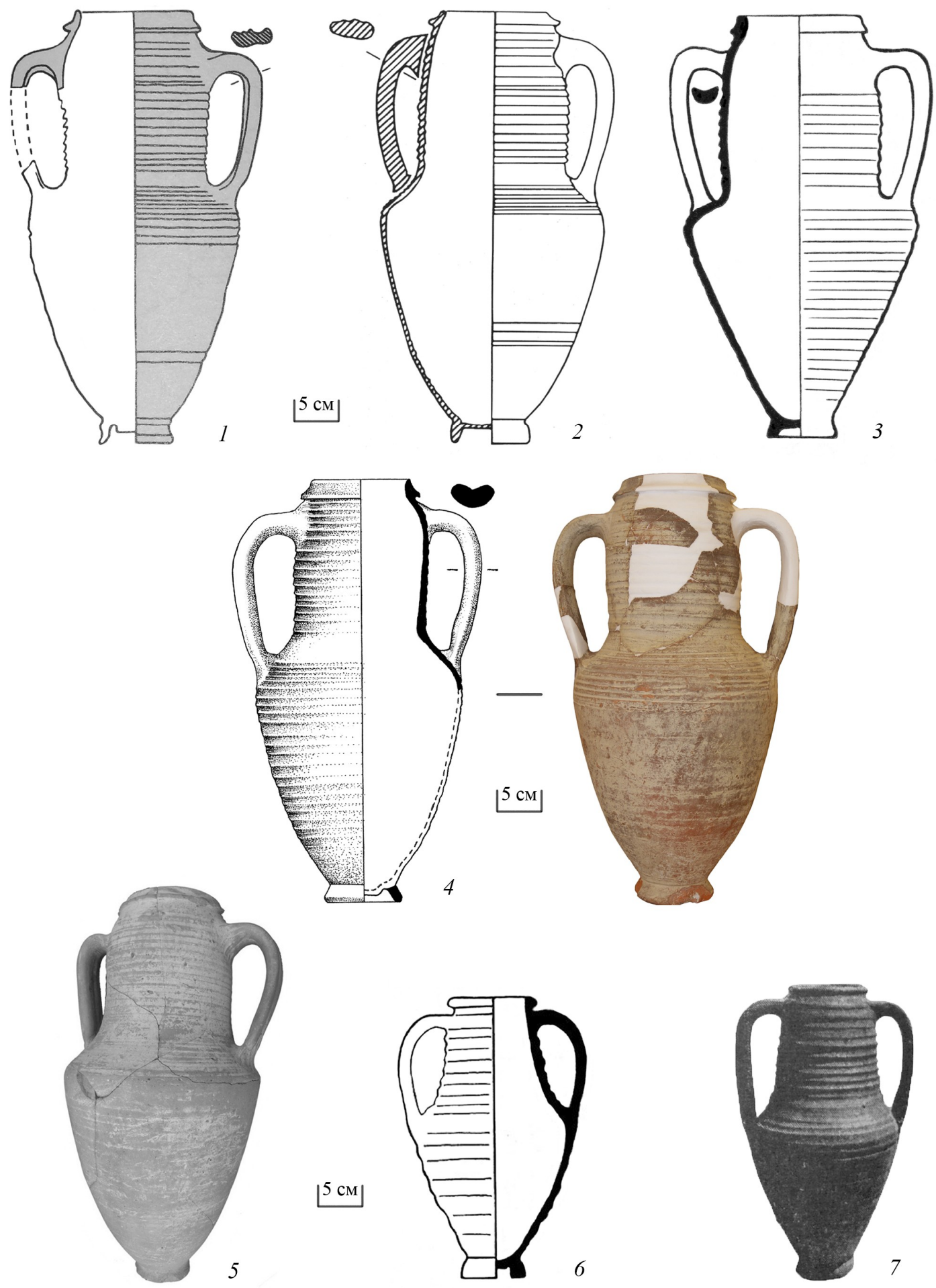

Рис. 2. Амфоры типа 27 по В.В. Крапивиной. Варианты а (1-5) и b $(6,7)$.

1, 2 - Танаис (по: Арсеньева, Науменко, 1992; Науменко, 2012); 3 - Горгиппия (по: Античные..., 1984); 4 - «Совхоз № 10» (чертеж по: Ораiț А., 2007); 5-7 - Ольвия (по: Krapivina, 2010; Ольвия..., 1999) 
Анализ ареала распространения исследуемых амфор позволяет сделать предположение об их производстве в Северном Причерноморье. С.Ф.Стржелецкий отнес сосуды из могильника «Совхоз № 10» к продукции Херсонеса ${ }^{32}$. Отметим, что на одном из них имеются следы производственного брака в виде растрескивания дна 33 . А. Опайц считает, что часть амфор рассматриваемого типа могли изготавливать недалеко от этого античного города, на территории современной Балаклавы ${ }^{34}$. По мнению В.В. Крапивиной, этим производственным центром мог быть Боспор 35 . Следует отметить, что керамическое тесто тирских экземпляров по визуальным признакам очень близко к глине амфор типов 72, 73 и 75 по И.Б. Зеест, которые выпускались на территории Боспора в рассматриваемый период 36.

А. Опайц относит амфоры типа 27 по В.В. Крапивиной к столовым 37 , однако они вполне могли использоваться в качестве тары - для транспортировки и хранения товаров. Так, небольшие размеры и оформление ножки в виде кольцевого поддона характерны для нескольких типов амфорной тары, которые в римское время выпускались в производственных центрах Средиземноморья ${ }^{38}$ и Южного Причерноморья ${ }^{39}$.

Довольно сложно определить, для перевозки каких товаров были предназначены интересующие нас амфоры, так как все они найдены без остатков содержимого. Дипинти на горлах сосудов, происходящих из Танаиса, относятся к группе именных и числовых, и информации о названии продуктов, которые находились в амфорах, не несут ${ }^{40}$. По мнению А. Опайца, в них могла содержаться соленая рыба (salsamentum), товарное производство которой было налажено в Крыму в римское время41. Крупные рыбоперерабатывающие комплексы I-III вв. н.э. были открыты в Херсонесе и на Боспоре 42 . Определенные свидетельства в пользу этого предположения можно получить проанализировав особенности морфологии тары. Так, очень широкое и высокое горло в сочетании с коротким туловищем не характерны для амфор, в которых перевозили вино или оливковое масло, однако могли быть очень удобными при транспортировке и хранении соленой рыбы.

Следует отметить, что в позднеримское время доля боспорской продукции в амфорном импорте Тиры была довольно высокой. Помимо рассматриваемых сосудов,

\footnotetext{
32 Стржелецкий С.Ф. Указ. соч. С. 141, Рис. 4.

33 Амфора хранится в фондах национального заповедника «Херсонес Таврический», инв. № 29/36360.

34 Opaiț A. Op. cit. P. 116.

35 Krapivina V. Op. cit. P. 71.

36 Внуков С.Ю. Причерноморские амфоры І в. до н.э. - II в. н.э. Часть II. Петрография, хронология, проблемы торговли. Санкт-Петербург: Алетейя, 2006. С. 88, 89, 95.

37 Opaiţ A. Op. cit. P. 115, 116.

38 Peacock D., Williams D. Amphorae and the Roman economy. London-New York: Longman, 1991. 1991, P. $142-145,175,176,180,181$.

39 Внуков С.Ю. Указ. соч. С. 16, Рис. 1, 6-10, 14, 15.

40 Ильяшенко С.М. Стандартные dipinti на узкогорлых светлоглиняных амфорах Танаиса и его округи III-IV вв. н.э. // Боспорские исследования. 2013. Вып. XXIX. С. 79-81, 85, Рис. 23, 1, 24, 1-4.

41 Opaiţ A. Op. cit. P. 116-118.

42 Кадеев В.И. Очерки истории экономики Херсонеса Таврического в I-IV вв. н.э. Харьков: Изд-во Харьковского университета, 1970. С. 5, 12-15; Кругликова И.Т. Сельское хозяйство Боспора. Москва: Наука, 1975. С. 209-212; Зинько А.В. Рыбозасолочный промысел в Тиритаке в III в. н.э. // Боспорские исследования. 2006. Вып. ХІ. С. 177.
} 
она представлена амфорами типов 72, 73, 83 и 75 по И.Б. Зеест ${ }^{43}$. Если находки фрагментов первых трех типов немногочисленны, то амфоры типа 75 по И.Б. Зеест являются одной из наиболее распространенных разновидностей керамической тары в Тире во второй половине II - первой половине III вв. н.э.44. Как и амфоры типа 27 по В.В. Крапивиной эти сосуды могли использовать для перевозки соленой рыбы 45 , однако они были более вместительными. Объем таких сосудов составляет около 135 литров ${ }^{46}$, хотя встречаются небольшие экземпляры емкостью от 30 до 60 литров ${ }^{47}$. В отличие от амфор типа 27 по В.В. Крапивиной эти сосуды получили широкое распространение в причерноморском регионе, а отдельные экземпляры зафиксированы и в Средиземноморье ${ }^{48}$. Причины такого неравномерного распределения можно связать с особенностями организации производства амфорной тары в рассматриваемый период. Вероятно, сосуды крупных размеров были более практичными для перевозки и хранения соленой рыбы, поэтому керамические мастерские ориентировались в основном на изготовление массивных амфор типов 75 и 83 по И.Б. Зеест ${ }^{49}$.

Таким образом, на протяжении III в. н.э. с территории Боспора в Тиру поступали два морфологических варианта амфор типа 27 по В.В. Крапивиной. Содержащийся в них товар, по всей видимости, salsamentum, закупался населением города и не предназначался для последующей перепродажи варварским племенам. На это косвенно указывает отсутствие находок рассматриваемой разновидности тары на синхронных археологических памятниках Нижнего Поднестровья. Вероятно, ввоз исследуемых амфор в Тиру осуществлялся напрямую, хотя не исключены поставки из Ольвии в результате торговых операций, носящих посреднический характер. Их количество в керамическом комплексе Тиры, по сравнению с другими разновидностями боспорской тары, невелико. Такое соотношение характерно для всех крупных античных центров, где были зафиксированы амфоры типа 27 по В.В. Крапивиной, и может быть связано небольшими объемами их производства.

\section{REFERENCES}

Alekseeva, E.M. (1997). Antichnyi gorod Gorgippiia [The ancient city of Gorgippia]. Moskva [in Russian]. Antichnye gosudarstva Severnogo Prichernomoria [Ancient states of the Northern Black Sea region] (1984). Seriia: Arkheologiia SSSR. Moskva: Nauka [in Russian].

\footnotetext{
43 Масюта Д.А. К вопросу об импорте рыбопродуктов в Тире во II-III вв. н.э. // Cultural heritage: research, valorization, promotion, Ed. a 10-a: Prin știinţă spre cunoaşterea patrimoniului naţional: Programul și rezumatele comunicărilor, (Chişinău, 30-31 mai 2018). Chişinău: Institutul Patrimoniului Cultural, 2018. P. 89.

44 Самойлова Т.Л. Основные типы амфор I-IV вв. н.э. из Тиры // Археологические исследования Северо-Западного Причерноморья (отв. ред. П.О. Карышковский). Киев: Наукова думка, 1978. С. 58; Масюта Д.А. Указ. соч. Р. 89.

45 Стржелецкий С.Ф., Высотская Т.Н., Рыжова Л.А., Жесткова Г.И. Указ. соч. С. 69; Opaiţ А. Op. cit. Р. 110. ${ }^{46}$ Науменко С.А. Указ. соч. С. 71.

47 Opaiţ A., Paraschiv D. On the wine, olive oil and fish supply of the countryside in Roman Dobroudja (1 1 st - $3^{\text {rd }}$ centuries AD) // Production and Trade of Amphorae in the Black Sea. PATABS III. Actes de la Table Ronde internationale de Costanța, 6-10 octobre 2009. Costanța, 2013. P. 320.

${ }^{48}$ Dyczek P. Roman amphorae of the $1^{\text {st }}-3^{\text {rd }}$ centuries AD found on the Lower Danube. Typology. Warszaw: Wydawnictwa Universytetu Warszawskiego, 2001. P. 236; Bezeczky T. The amphorae of Roman Ephesus // Forschungen in Ephesos. XV/1. Wien: Verlag der Österreichischen Akademie der Wissenschaften, 2013. P. 173.

49 Зеест И.Б. Керамическая тара Боспора // Материалы и исследования по археологии СССР. Вып. 83. 1960. С. 113, 115, 116, Табл. XXXI, 75; XXXIV, 83.
} 
Arseneva, T.M., \& Naumenko, S.A. (1992). Usadby Tanaisa [Manors of Tanais]. Moskva: Izdatelstvo IA RAN [in Russian].

Arseneva, T.M., \& Naumenko, S.A. (1994). Kompleks nakhodok iz podvala MB II-III vv. n.e. [The Complex of Finds from Cellar MB of the 2nd-3rd centuries AD]. Vestnik Tanaisa, 1, 61-113 [in Russian].

Bezeczky, T. (2013). The Amphorae of Roman Ephesus. Forschungen in Ephesos, XV/1. Wien: Verlag der Österreichischen Akademie der Wissenschaften [in English].

Dyczek, P. (2001). Roman Amphorae of the 1st-3rd centuries AD Found on the Lower Danube. Typology. Warszaw: Wydawnictwa Universytetu Warszawskiego [in English].

Gaidukevich, V.F. (1987) Antichnye goroda Bospora. Mirmekii [Ancient cities of the Bosporus. Mirmekion]. Leningrad: Nauka [in Russian].

Iliashenko, S.M. (2013). Standartnye dipinti na uzkogorlykh svetloglinianykh amforakh Tanaisa i ego okrugi III-IV vv. n.e. [Standard dipinti on Narrow-necked Light Clay Amphorae from Tanais and its Vicinity in the $3^{\text {rd- }} 4^{\text {th }}$ centuries AD]. Bosporskie issledovaniia, XXIX [in Russian].

Kadeev, V.I. (1970). Ocherki istorii ekonomiki Khersonesa Tavricheskogo v I-IV vv. n.e. [Essays on the History of the Economy of Chersonesos Tauricus in the $1^{\text {st }} 4^{\text {th }}$ centuries AD]. Kharkov: Izdatelstvo Kharkovskogo universiteta [in Russian].

Krapivina, V.V. (1993). Olviia. Materialnaia kultura I-IV vv. n.e. [Olbia. The Material Culture of the $1^{\text {st- }} 4^{\text {th }}$ centuries AD]. Kiev: Naukova dumka [in Russian].

Kruglikova, I.T. (1975). Selskoe khoziaistvo Bospora [The agriculture of the Bosporus]. Moskva: Nauka [in Russian].

Kryzhitskii, S.D., $\quad$ Rusiaeva, A.S., $\quad$ Krapivina, V.V., $\quad$ Leipunskaya, N.A., $\quad$ Skrzhinskaia, M.V., ～\& Anokhin, V.A. (1999). Olviia. Antichnoe gosudarstvo v Severnom Prichernomore [Olbia. The Ancient City in the Northern Black Sea region]. Kiev: Izdatelstvo IA NANU [in Russian].

Leipunskaia, N.A. (1984). Keramika iz zatoplennoi chasti Olvii [Pottery from the Flooded Part of Olbia]. In Kryzickii, S.D. (Ed.) Antichnaia kultura Severnogo Prichernomoria (pp.65-88). Kiev: Naukova dumka [in Russian].

Masyuta, D.A. (2018). K voprosu ob importe ryboproduktov v Tire vo II-III vv. n.e. [To the Issue of Import of Fish Products in Tyras in the $2^{\text {nd }} 3^{\text {rd }}$ centuries AD]. In Cultural heritage: research, valorization, promotion, Ed. a 10-a: Prin ştiinţă spre cunoaşterea patrimoniului naţional: Programul şi rezumatele comunicărilor, Chișinău (30-31 mai 2018), (pp. 89-90). Chișinău: Institutul Patrimoniului Cultural [in Russian].

Naumenko, S.A. (2012). Sostav amfor v zakrytykh kompleksakh Tanaisa kontsa I - serediny III vv. n.e. [The Composition of Amphorae in Closed Complexes of Tanais of the End of the $1^{\text {st }}$ - the Middle of the $3^{\text {rd }}$ centuries AD]. Vestnik Tanaisa, 3, 63-88 [in Russian].

Samoilova, T.L. (1978). Osnovnye tipy amfor I-IV vv. n.e. iz Tiry [The Main Types of Amphorae of the $1^{\text {st }} 4^{\text {th }}$ centuries AD from Tyras]. In Karyshkovskii, P.O. (Ed.). Arkheologicheskie issledovaniia SeveroZapadnogo Prichernomoria, (pp. 254-266). Kiev: Naukova dumka [in Russian].

Samoilova, T.L., Kozhokaru, V., \& Boguslavskii, G.S. (2002). Antichnaia Tira - srednevekovyi Belgorod (otchet o raskopkakh za 1996-1999 gg.) [Ancient Tyra - medieval Belgorod (excavation report for 1996-1999)]. In Roman, P., Kryzhitskiy, S. (Ed.). Tyras - Cetatea Albă / Belhorod-Dnistroskyj. Săpături 1996-1999, Vol. I. (pp. 159-186). Buharesti [in Russian].

Strzheletskii, S.F. (1959). Pozdneantichnyi mogilnik v Inkermanskoi doline [The Late Antique necropolis in the Inkerman Valley]. Kratkie soobshcheniia Instituta arkheologii AN USSR, 8, 139-145 [in Russian].

Strzheletskii, S.F., Vysotskaia, T.N., Ryzhova, L.A., \& Zhestkova, G.I. (2005). Naselenie okrugi Khersonesa v pervoi polovine I tysiacheletiia novoi ery (po materialam nekropolia «Sovkhoz № 10») [The Population in the Neighborhood of Chersonesos in the 1st millennium AD (by Materials of the Necropolis «Sovkhoz № 10»)]. Stratum plus, 4, 27-277 [in Russian].

Krapivina, V. (2010). Amphorae of the $3^{\text {rd- }} 4^{\text {th }}$ centuries A.D. in Olbia Pontica. In Production and Trade of Amphorae in the Black Sea. PATABS I: Actes de la Table Ronde internationale de Batoumi et Trabzon, 27-29 Avril 2006. Varia Anatolica. XXI, (pp. 69-73). Istanbul-Paris [in English].

Opaiț, A. (2007). A Weighty Matter: Pontic Fish Amphorae. In The Black Sea in antiquity: Regional and interregional economic exchanges. Black Sea Studies. 6. (pp. 101-122). Aarhus: Aarhus University Press [in English].

Opaiţ, A., \& Ionescu, M. (2016). Contributions to the Economic Life of the City of Callatis in Light of New Ceramic Finds (2nd-6 th centuries AD). Arheologia Moldovei, XXXIX, 57-112 [in English].

Opait, A., \& Paraschiv, D. (2013). On the Wine, Olive Oil and Fish Supply of the Countryside in Roman Dobroudja ( $1^{\text {st }}-3^{\text {rd }}$ centuries AD). In Production and Trade of Amphorae in the Black Sea. PATABS III. Actes 
de la Table Ronde internationale de Costanța, 6-10 octobre 2009 (pp. 317-333). Costanța [in English].

Peacock, D., \& Williams, D. (1991). Amphorae and the Roman Economy. London-New York: Longman [in English].

Vnukov, S.Yu. (2006). Prichernomorskie amfory I v. do n.e. - II v. n.e. Chast II. Petrografiia, khronologiia, problemy torgovli [The Black Sea Amphorae of the $1^{\text {st }} c$. BC - the $2^{\text {nd }} c$. AD II: Petrography, chronology and trade questions]. Sankt-Peterburg: Aleteia [in Russian]

Zeest, I.B. (1960). Keramicheskaia tara Bospora [Ceramic vessels of Bosporus]. Seriia: Materialy i issledovaniia po arkheologii SSSR, no. 83. Moskva: Izdatelstvo Akademii Nauk SSSR [in Russian]

Zinko, A.V. (2006). Rybozasolochnyi promysel v Tiritake v III v. n.e. [Fishery in Tiritaka in the $3^{\text {rd }}$ century AD]. Bosporskie issledovaniia, XI, 177-186 [in Russian].

\section{Denis Masyuta}

(The Odessa Archaeological Museum, Odesa, Ukraine)

ORCID: https://orcid.org/0000-0002-3722-154X

\section{Type 27 Amphorae from Tyras According to V.V. Krapivina's Classification}

Over the past two decades, as a result of systematic archaeological research of Tyras, there has been accumulated impressive material that makes it possible to supplement the composition of its ceramic complex with several types of amphora containers. The amphorae of type 27 according to V.V. Krapivina's classification belong to one of the rarest types.

These vessels are characterized by small size, wide, high neck, egg-shaped body, profiled handles, toe in the form of the cylindrical tray. Based on morphological differences, the amphorae of the studied type can preliminary be divided into two variants (a and b). 27a includes larger vessels with beak-shaped rims, and to $27 \mathrm{~b}$ belong small items with rolled rims.

During the archaeological excavations of Tyras, amphorae of both variants were found, originating from archaeological contexts with a wide dating. Variant $27 \mathrm{a}$ is represented by fragments of profile parts, and two fragmented vessels belong to variant $27 \mathrm{~b}$.

Area of distribution of type 27 amphorae according to V.V. Krapivina covered predominantly the Northern Black Sea region, to the markets of which they came throughout the $3^{\text {rd }}$ century AD. One item was found in the western part of the Pontic region, while in the Southern and Eastern Black Sea regions, as well as in the Mediterranean, such vessels have not been found yet.

Findings of the considering type of ceramic vessels mainly originate from archaeological excavations of ancient cities.

Some amphorae of type 27 according to V.V. Krapivina could be produced in the neighborhood of Chersonesos, however, the main production volume was most likely produced on the territory of Bosporus. The color of their clay, as well as the visually distinct features of its composition, prove Bosporus origin of the vessels found in Tyras.

Analysis of the amphorae morphology of the type under consideration suggests that they were intended for transportation and storage of salted fish (salsamentum), the commodity production of which was set up in Chersonesus and Bosporus in Roman times.

Thus, throughout the $3^{\text {rd }}$ century AD, two morphological variants of type 27 amphorae according to V.V. Krapivina were imported from the territory of Bosporus to Tyras. The product contained in them, apparently, salsamentum, was purchased by the population of the city and was not intended for resale to barbaric tribes. This is indirectly indicated by the absence of findings of the considering type of containers at the synchronous archaeological sites of the Lower Dniester region.

Probably, the studied amphorae came to Tyras directly, though the supplies from Olbia, as a result of intermediary trade operations, are not excluded.

Keywords: amphora containers, morphology, chronology, Late Roman time, Tyras 


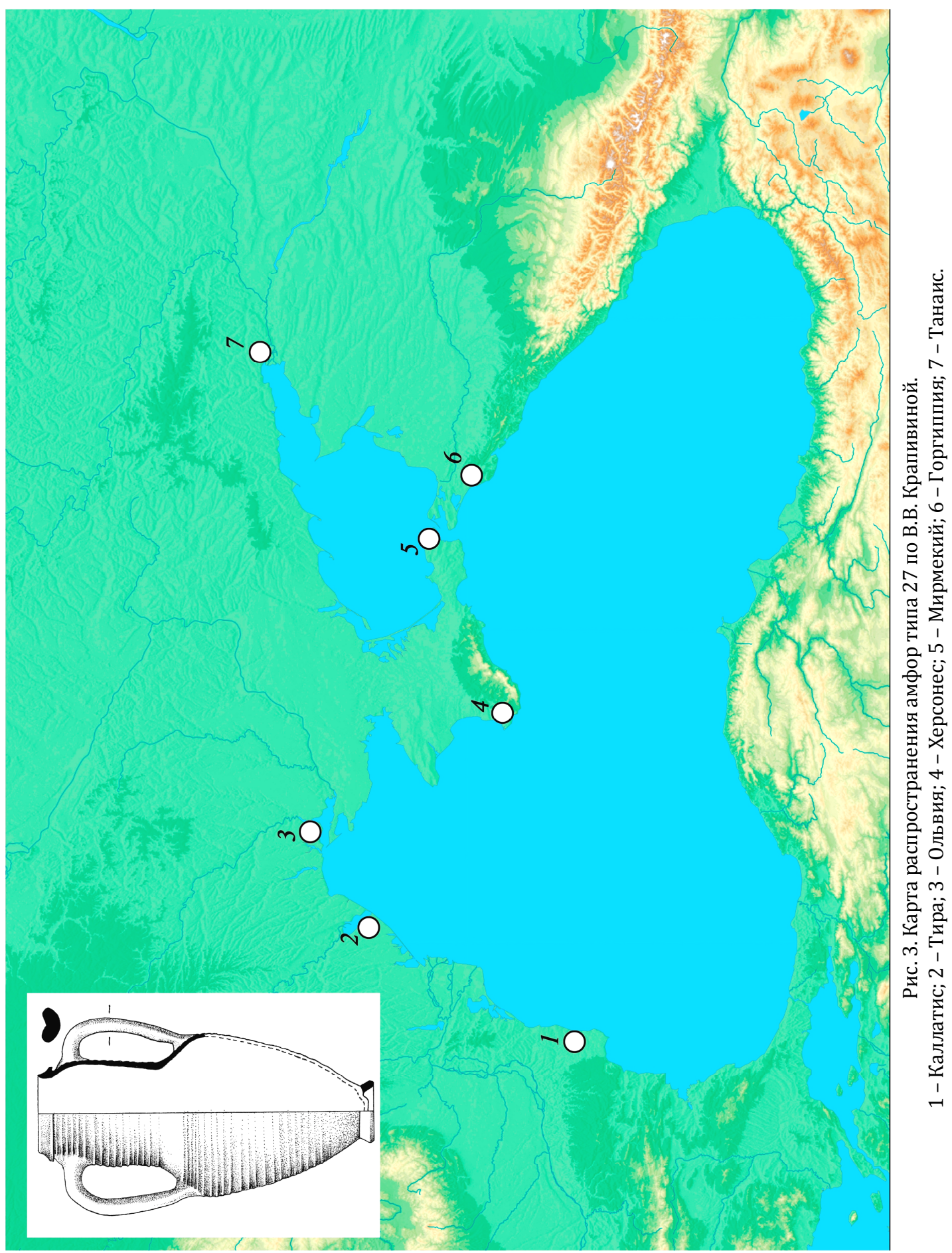

